\title{
Pemahaman petugas kehumasan Kementerian Dalam Negeri tentang peran Humas Pemerintah
}

\begin{abstract}
ABSTRAK
Pelaksanaan tugas pokok Pemerintah yakni Pelayanan, pemberdayaan dan pembangunan yang dilakukan pada masyarakat berusaha dioptimalkan melalui berbabagi revitalisasi salah satunya adalah dengan membuat Peraturan Menteri Dalam Negeri No. 13/2011 dimana dalam peraturan tersebut dijelaskan bahwa Humas Pemerintah termasuk Humas Kemendagri berperan sebagai tempat komunikasi Pemerintah kepada masyarakatnya sekaligus menjalankan peran Pemerintah untuk memberikan informasi yang transparan sesuai dengan tuntutan publik. Lahirnya Permendagri 13/2011 menuntut Kemendagri untuk melakukan pembenahan dan peningkatan sumber daya manusia yang menempati posisi di lembaga Kehumasan di lingkungannya termasuk pmenanamkan pemahaman peran Humas Pemerintah pada tenaga Humas di Kementerian Dalam Negeri. Tujuan dari penelitian ini adalah mengetahui Pemahaman petugas kehumasan Kementerian Dalam Negeri tentang peran Humas Pemerintah. Penelitian ini menggunakan metode studi kasus yang tergolong sebagai satu objek (single case study) dengan penentuan key informan yakni purposif. Hasil dan pembahasan dari penelitian ini diketahui bahwa pemahaman petugas kehumasan Kementerian Dalam Negeri tentang peran Humas Pemerintah adalah sebagai berikut: 1) Menciptakan goodwill; 2) Menjaga hubungan baik dengan Stakeholder; 3) Membangun pemahaman masyarakat tentang kebijakan Pemerintah; dan 4) Membangun kepercayaan (trust) masyarakat terhadap sebuah pemerintahan. Simpulan dan saran dari penelitian ini adalah Humas Pemerintah Kemendagri telah menyadari pentingnya peran Humas dalam sebuah lembaga Pemerintahan dan perlu dilakukan revitalisasi untuk mengoptimalkan peranannya. Sebaiknya Humas Pemerintah Kemendagri melakukan revitalisasi berupa penempatan SDM yang berlatarbelakang Humas dalam struktur Humas Pemerintah, dilakukan inovasi dalam mengoptimalkan peran Humas.
\end{abstract}

Anwar Sani $^{1}$, Mien Hidayat ${ }^{2}$, Nuryah Asri Sjafirah ${ }^{3}$

${ }_{1,2,3}$ Universitas Padjadjaran, Bandung, Indonesia

Kata-kata Kunci: Humas pemerintahan; peran humas; petugas kehumasan; kementerian; peraturan menteri

\section{Ministry of home affairs' public relation staff understanding on government public relations}

\section{ABSTRACT}

The implementation of the main tasks of the Government, namely Service, empowerment, and development, is carried out by optimizing through shared revitalization. One of which is by producing the Minister of Home Affairs Regulation No. 13/2011, which explains in the regulation that Government Public Relations including the Public Relations of Ministry of Home Affairs have a role as a communication medium between the Government and the public and at the same time carry out the Government's role in providing information openness for public. The issuance of Permendagri 13/2011 requires the Ministry of Home Affairs to reform and increase its human resources occupying positions in public relations institutions, which include providing an understanding of the role of Government Public Relations for Public Relations personnel in the Ministry of Home Affairs. The purpose of this study was to determine the understanding of the Ministry of Home Affairs public relations officers on the role of Government Public Relations. This study uses a single case study method with purposive sampling for the key informants. The results show that the understanding of the Ministry of Home Affairs public relations officers about the role of Government Public Relations is as follows: 1) Creating goodwill; 2) Maintaining good relations with stakeholders; 3) Building public understanding of Government policies, and 4) Building public trust in a government. The conclusion for this research is that Public Relations of the Ministry of Home Affairs have perceived the importance of the role of Public Relations in a government agency and need to be revitalized to optimize its role. The recommendation from this research is that Public Relations of the Ministry of Home Affairs in optimizing the role of Public Relations conduct a revitalization in the form of arranging placement of human resources with a Public Relations background in the structure of the Government Public Relations.

Keywords: Government public relations; the role of public relations; public relations officer; ministry; ministerial regulation

Korespondensi: Anwar Sani, S.Sos., M.I.Kom. Universitas Padjadjaran.Jl. Raya Bandung Sumedang KM.21, Hegarmanah, Kec. Jatinangor, Kabupaten Sumedang, Jawa Barat 45363.Email: anwar.sani@unpad. ac.id 


\section{PENDAHULUAN}

Pelayanan, pemberdayaan, dan pembangunan yang dilakukan pada masyarakat merupakan tugas pokok Pemerintah. Hal tersebut secara implisit dituangkan dalam pembukaan UUD 1945. Dengan demikian ,pemerintah mempunyai tugas pokok dan peran yang sangat luas dan kompleks. Terlebih proses demokratisasi. Kondisi tersebut berimbas pada: Pertama, tingginya tuntutan masyarakat akan akan transparansi, akuntabilitas dan partisipasi publik dalam implementasi peranperan pemerintahan. Kedua, bagaimana pelayanan dan kebijakan publik yang dilakukan memenuhi tuntutan aspek transparansi, akuntabilitas dan partisipasi publik tadi. Dalam upaya mewujudkan hal tersebut pemerintah membutuhkan sumberdaya, dukungan lingkungan dan kelembagaan yang kuat.

Peran Humas Pemerintah khususnya setelah era reformasi yang semakin berkembang menjadi sangat penting. Masyarakat menuntut adanya transformasi informasi dari Pemerintah, sekaligus berperan besar sebagai komunikator pemerintah guna menyebarluaskan informasi ke seluruh stakeholder pemerintah. Menteri Komunikasi dan Informatika dalam Pertemuan Tematik Kehumasan Otoritas Jasa Keuangan (OJK) di Jakarta mengungkapkan jika terdapat perbedaan antara Peran Humas dahulu dengan sekarang. Media sudah lebih transparan dalam memberikan informasi pada publik berbeda dengan dahulu sebelum reformasi yang semua dikendalikan oleh Pemerintah (Kominfo, 2016).

Perubahan wajah humas pemerintah dari yang cenderung 'tradisional' menjadi lebih 'modern' itulah kesan yang menyeruak dari Permendagri No. 13/2011. Keputusan Menteri Dalam Negeri Nomor 51 Tahun 1998 tentang Pedoman Pelaksanaan Tugas-Tugas Kehumasan di Jajaran Departemen Dalam Negeri dan Pemerintah Daerah, sebagai pendahulu Permendagri No. 13/2011 dinilai sudah tidak sesuai dengan perkembangan jaman. Lengsernya era pemerintahan Orde Baru yang otoriter merangsang tumbuhnya kekuatan civil society sehingga terbukanya saluransaluran komunikasi yang dulu tersumbat.

Berdasarkan Pedoman Umum Tata Kelola Kehumasan di Lingkungan Instansi Pemerintah yang dikeluakan oleh Kementrian PAN RB tahun 2011, adanya reformasi birokrasi juga menuntut Humas Pemerintah untuk melaksanakan model Kehumasan berdasar pada transparansi dan akuntabilitas informasi. Untuk itu, diperlukan model komunikasi dua arah agar tercapai komunikasi yang interaktif dengan publik (RI, 2011).

Dinamika perubahan ini melahirkan peran media, Lembaga Swadaya Masyarakat (LSM), pengamat hingga kaum intelektual 
sebagai kekuatan yang mengurangi peran negara. Dengan demikian peran Humas sebagai komunikator politik yang merepresentasi pemerintah semakin strategis. Pada Rakor Nasional Kehumasan dan Hukum tahun 2019, Mendagri menjelaskan, bahwa peran Humas Pemerintah adalah menjembatani hubungan pimpinan instansi dengan berbagai pihak dalam menyebarluaskan program dan kegiatan pemerintah (Semangatnews, 2019).

Melihat pentingnya peran Humas pada Pemerintah, praktisi PR harus menguasai peran Humas Pemerintah. (Astuty, Setyastuti, Maulina, \& Hanief, 2017) menjelaskan hasil dari penelitiannya adalah jika SDM praktisi Humas minim latar belakang PR, maka mungkin saja menjadi penyebab terdapat praktisi Humas yang hanya terbatas pada menjalankan peran sebagai fasilitator komunikasi dan teknisikomunikasi.

Data tersebut di atas perlu diminimalisir dengan peningkatan mutu praktisi Humas Pemerintah di tengah transformasi peran Humas Pemerintah. Humas Pemerintahan bertransformasi menjadi Humas yang modern salah satunya dengan mengadopsikonsep Humas sebagai koalisi dominan dalam organisasi. Humas harus terlibat aktif dalam proses pengambilan keputusan yang memutuskan perencanaan strategik. Konsep koalisi dominan dalam hal ini menuntut posisi Humas Kemendagri untuk memiliki kewenangan lebih dalam memberi arah perkembangan organisasi termasuk menentukan visi, misi, perangkat serta struktur kelengkapan organisasi. Koalisi ini merupakan penentu dalam pengambilan keputusan dan yang mengendalikan berputarnya roda organisasi.

Upaya menyebarluaskan informasiinformasi pemerintah ke seluruh stakeholder, menjadi sulit bagi pejabat Humas pemerintah, jika akses terhadap sumber informasi pemerintahan terhambat oleh sekat-sekat birokrasi. Sekat-sekat ini harus diruntuhkan dengan menempatkan pejabat Humas pada tingkatan dalam struktur organisasi yang lebih strategis. Seiring dengan arahan konsep koalisi dominan kehumasan, Humas Kementerian Dalam Negeri kini berada di bawah Sekretariat Jenderal Kementerian Dalam Negeri, sehingga akses informasi dengan Menteri dan jajaran pengambil keputusan lainnya yang merupakan episentrum informasi semakin dekat dan terbuka.

Peran Humas Pemerintah dalam (RI, 2011) adalah sebagai komunikator yakni membuka akses dan saluran komunikasi dua arah, antara instansi pemerintah dan publiknya, baik secara langsung maupun tidak langsung, melalui sarana kehumasan, berperan sebagai fasilitator, diseminator, katalisator, konselor, dan prescriber.

Humas Pemerintah memberikan informasi 
kepada masyarakat berkaitan dengan kebijakan, program dan kegiatan pemerintah seperti termaktub dalam poin a. pasal 3 Permendagri 13/2011, merupakan ruh dari metode public relations pada level organisasi manapun. Keberadaan PR merupakan komunikator lembaga terhadap masyarakat umum sebagai publiknya. Adapun kebijakan, program dan kegiatan pemerintah merupakan pesan aktivitas PR.

Praktisi PR berperan mengumpulkan, mengolah dan mengemas pesan-pesan tersebut untuk disampaikan pada publiknya melaui medium komunikasinya. Sebagai contohnya, informasi yang tengah menjadi pekerjaan besar bagi Kemendagri adalah Kartu Tanda Penduduk Elektronik atau E-KTP. Sosialisasi tentang latar belakang mengapa harus berubah dari KTP konvensional menjadi E-KTP, manfaat E-KTP, bagaimana proses pengurusan E-KTP hingga kapan dan dimana mengurus E-KTP menjadi tema-tema kebijakan yang kemudian diolah untuk menjadi informasi Humas Kemendagri kepada masyarakat.

Kemampuan ini digunakan untuk bisa mengemas pesan yang menarik, proporsional dan akurat sekaligus cepat. Hingga informasi kebijakan, program dan kegiatan pemerintah dapat secara lengkap, utuh, tepat dan benar sampai kepada masyarakat. Faktor keselarasan kemudian menjadi modal utama guna mempermudah upaya pemerintah dalam membangun pemahaman dan kesamaan visi, misi serta persepsi dengan masyarakat. Seperti yang diatur dalam poin d pasal 3 Permendagri $13 / 2011$.

Persoalan membangun pemahaman dan kesamaan visi, misi serta persepsi masyarakat terhadap pemerintah adalah pekerjaan rumah besar bagi para profesional komunikator pemerintah. Kondisi Indonesia yang majemuk secara kultur dan geografis semakin membuat upaya penyamaan visi, misi dan persepsi dalam segala bidang akan semakin kompleks. Melihat kenyataan ini maka public relations sebagai metode komunikasi pemerintah pada rakyatnya menjadi sangat strategis. Hal ini menuntut profesional humas pemerintah untuk memahami setiap karakter masyarakatnya. Karena kunci penyamaan persepsi dalam public relations adalah diawali dengan pemahaman akan karakter dan kebutuhan publik. Sekali lagi dalam hal ini dibutuhkan kemampuan profesional PR untuk berempati, membuka diri pada realitas perubahan dan dinamika pada ranah publik.

Pada poin e pasal 3 Permendagri 13/2011 ditegaskan bahwa Humas Kemendagri bertugas menampung aspirasi publik sebagai masukan dalam mengevaluasi kebijakan, program dan kegiatan pemerintah. Tugas ini menjadi ciri khas metode public relations. PR merupakan 
metode komunikasi 2 arah. Tidak harus selalu pada arah komunikasi lembaga pada publiknya, melainkan juga publik kepada lembaga. Feedback masyarakat memegang peranan strategis dalam hubungan antara lembaga dan publik. Opini dan kritik publik pada pemerintah, dalam perspektif PR modern, demikian juga dalam iklim demokratisasi, merupakan elemen strategis bagi terbentuknya kebijakan lembaga. Sudah menjadi dambaan publik agar sebaiknya setiap kebijakan lembaga, dalam hal ini pemerintah, harus berwarna atau diwarnai oleh kepentingan masyarakat. PR sebagai sebuah metode komunikasi memiliki kemampuan untuk menjaring atau menangkap kepentingan masyarakat yang direpresentasikan oleh opini publik. Sekali lagi, kemampuan serta kepekaan terhadap dinamika opini publik dalam hal ini menjadi kemampuan yang sangat krusial bagi para pelaku humas pemerintah.

Sementara itu aspek yang berkaitan dengan ruang lingkup yang menjadi tanggung jawab lembaga kehumasan di lingkungan Kemendagri, menurut Permendagri 13/2011 antara lain adalah manajemen hubungan masyarakat; hubungan kerja dan koordinasi antar lembaga; pengembangan analisa media dan informasi; manajemen komunikasi krisis; analisa pemberitaan media massa; tatakelola infrastruktur kehumasan; konsultasi publik; pelayanan dan penyebarluasan informasi dan dokumentasi; pengawasan penyelenggaraan kehumasan; dan evaluasi penyelenggaraan kehumasan (Pasal 10, Permendagri 13/2011).

Poin-poin yang termaktub pada pasal 10 Permendagri 13/2011 merepresentasikan sebuah kemauan Kemendagri untuk melakukan optimalisasi peran Humas Kemendagri. Sebuah dasar regulasi yang mendorong upaya transformasi wajah dan mind set Humas Kemendagri dari gaya lama yang birokratif ke gaya baru yang lebih korporatif, transparan dan membangun hubungan publik yang harmonis sekaligus dinamis.

Perubahan posisi Humas Kemendagri pada organigram Kemendagri ini akan mempermudah hubungan kerja dan koordinasi antar lembaga. Artinya dengan semakin strategisnya posisi Humas Kemendagri, mempermudah profesional Humas Kemendagri untuk melakukan koordinasi dengan lembagalembaga di lingkungan internal Kemendagri maupun lembaga-lembaga eksternal lainnya.

Hal ini mencirikan aroma transformasi yang telah diungkapkan sebelumnya. Kemendagri selama ini berwarna birokratif dan kaku, hal ini salah satunya disebabkan oleh selera penguasa orde baru yang selalu memberikan nuansa militeristik pada kementerian ini. Sejak tahun 1964 hingga 2009 Menteri Dalam Negeri Republik Indonesia selalu berasal dari ABRI/ TNI. Hal ini dilatarbelakangi oleh situasi 
politik dalam negeri Indonesia yang tengah panas pada era tahun 60 -an. Penempatan sosok militer pada kementerian ini seolah menjadi tren dengan dalih stabilisasi politik dalam negeri. Selama 4 dasawarsa dikepalai 13 menteri berlatar belakang, jenderal tepatnya, menjadikan Kemendagri menjadi departemen atau kementerian yang berwarna militer pula.

Fenomena ini kemudian menjadi sangat kontradiktif dengan posisi strategis Kemendagri sebagai ujung tombak pelayanan publik pemerintah pada masyarakatnya. Terlebih memasuki era reformasi, wajah militeristik ini seolah kontra produktif dengan semangat demokratisasi yang tengah menggelora pada bangsa ini. Kementerian ini dituntut untuk lebih terbuka dan menyelaraskan diri dengan dinamika perubahan yang terjadi pada masyarakat Indonesia pada abad baru ini.

Pasal $10 \quad$ Permendagri 13/2011 merepresentasikan wajah humas modern yang korporatifdenganstakeholdernya. Salah satunya adalah media massa. Kemendagri menjadikan media sebagai mitra. Kemendagri membuka diri dengan kelompok media. Memberikan informasi yang cepat, akurat dan proporsional pada media massa tentang kebijakan dan program-program pemerintah. Mereka sadar bahwa posisi media sebagai intervening public, membantu Kemendagri untuk menyebarluaskan informasi tentang kebijakan dan program- program pemerintah. Melalui program media relations pula Kemendagri juga menangkap feedback, opini dari publik guna dijadikan landasan bagi kebijakan dan program-program kementerian. Era keterbukaan informasi publik yang digagas oleh bangsa Indonesia pada dewasa ini mendorong Kemendagri untuk semakin menjalin hubungan harmonis sekaligus dinamis dengan media massa.

Poin g pada pasal 10 Permendagri 13/2011 menawarkan warna yang cukup istimewa. Humas Kemendagri memiliki tanggung jawab untuk melakukan konsultasi publik. Lagi-lagi ciri khas lembaga yang bertransformasi untuk menjadi lebih korporatif menyeruak pada klausul ini. Cirikomunikasi satu arah pemerintah pada publiknya perlahan ditinggalkan, dengan menciptakan media aspiratif dan informatif. Membuka diri pada pertanyaan-pertanyaan serta masukan dan memberikan konsultasi pada publik menjadi ciri khas tersendiri pada wajah Humas Kemendagri masa kini. Menjadi salah satu kata kunci dalam public relations, bahwa praktisi PR harus mampu menumbuhkan public interest.

Dalam hal ini, Permendagri 13/2011 memberikan arahan pada para pelaku kehumasan Kemendagri untuk memberikan pelayanan informasi publik yang berkualitas, memenuhi kebutuhan informasi publik tentang detail, seluk beluk hingga tata cara sebuah kebijakan 
atau program-program pemerintah. Sebagai komunikator lembaga, pelaku Kehumasan Kemendari juga dituntut untuk memiliki kemampuan mendengar keluhan sekaligus memberikan solusi bagi permasalahan relasi publik dengan pemerintah.

Lahirnya Permendagri 13/2011 menuntut Kemendagri untuk melakukan pembenahan dan peningkatan sumber daya manusia yang menempati posisi di lembaga kehumasan di lingkungannya. Perubahan gaya humas pemerintahan yang modern menyangkut persoalan budaya. Maka pada dasarnya melalui Permendagri No. 13/2011 diharapkan kultur Humas pemerintah mengalami transformasi budaya. Berubah dari pola dan kultur birokratif menjadi kultur korporatif. Budaya birokratif yang melekat pada peran, hingga kualitas SDM humas pemerintah yang cenderung kaku, tidak berani, tidak kreatif serta tidak peka terhadap perubahan dan tuntutan jaman, harus berubah menjadi humas yang berbudaya korporatif yang lebih mengedepankan semangat serta mentalitas kompetitif. Perubahan tersebut menurut Kapuspen, berdasarkan profesionalisme, kompetensi dan diferensiasi struktur.

Robert Leach membuat keterkaitan antara perkembangan demokrasi dan tuntutan peran Humas pemerintah yang ideal. Democracy is now taken for granted over much of the modern world, although for nearly all states it is relatively recent, fragile and imperfect. The growth of public relations has been linked to the growth of democracy, as the need arose to communicate persuasively (Tench \& Yeomans, 2006).

Indonesia dalam konteks tersebut merupakan negara yang mengklaim sebagai negara demokratis, sehingga keterbukaan informasi dan komunikasi antara pemerintah dan warga negara menjadi sebuah ikon demokrasi yang tidak bisa dilepaskan. Komunikasi politik yang persuasif antara pemerintah dengan warga negara merupakan kebutuhan mendasar untuk mendapatkan dukungan warga negara terhadap jalannya pemerintahan. Peran komunikasi persuasif tersebut salah satunya melekat pada Humas pemerintah. Ditegaskan kembali oleh Leach bahwa Humas (pemerintah) yang menjalankan peran dan peranannya secara ideal akan memberikan kontribusi positif dalam proses dinamika demokrasi. Leach dalam (Tench \& Yeomans, 2006) mengutip pendapat Cutlip, et al. bahwa :

"in a very real sense, the purpose of democracy itself closely matches the purpose of public relations. Successful democratic government maintains responsive relationships with constituents, based on mutual understanding and twoway communication.

Hal ini menegaskan bahwa Humas dan demokrasi tidak bisa dipisahkan satu dengan yang lain. Dengan menggunakan serangkaian upaya menciptakan saling pemahaman melalui 
medium-medium komunikasi dua arah, humas pemerintah dituntut pula harus memelihara hubungan secara responsif dan dinamis. Hingga keberhasilan suatu pemerintah menciptakan iklim demokrasi yang sehat akan mudah tercapai.

Jika pemerintah dapat menciptakan iklim demokrasi yang kondusif, maka masyarakat akan memberikan respon positif terhadap wacana atau kebijakan yang diciptakan pemerintah. Individu memaknai produk sosial secara objektif melalui interaksi bahkan secara tidak langsung, sehingga bahasa sangat berperan penting dalam menentukan objektivitas pesan sebuah lembaga. Hal ini menjadi penting diperhatikan dalam peran humas pemerintah.

Penelitian ini menganalisis fenomena melalui Teori Konstruksi Realitas Sosial. Melalui teori ini dapat diketahui peran humas pemerintah di lingkungan Kementrian Dalam Negeri Republik Indonesia terletak pada aspek pembuat kebijakan di lingkungan Kemendagri menyadari betul bahwa dalam era demokratisasi dan tuntutan keterbukaan informasi publik, peran humas pemerintah seharusnya menjadi sangat strategis. Humas pemerintah dituntut untuk menyelaraskan diri dengan percepatan dan dinamika perubahan. Kesadaran tuntutan akan upaya optimalisasi peran humas pemerintah ini merupakan bukti bahwa individu-individu pembuat kebijakan di Kemendagri, menurut teori konstruksi realitas sosial, telah melakukan tahap eksternalisasi seperti yang dimaksud dalam teori tersebut.

Penelitian ini menjadi penting untuk dilakukan karena implementasi peran humas pemerintah pada Kementrian Dalam Negeri ditengah tuntutan publik akan keterbukaan informasi, dapat memenuhi sebuah nilai unik dalam kasus sebagai ciri penelitian studi kasus dimana sebuah instansi Pemerintahan melakukan peranannya ditengah dinamika yang ada.

Oleh karena itu tujuan dari penelitian ini adalah untuk mengetahui pemahaman peran humas pemerintahan melalui perspektif petugas kehumasan di kementerian dalam negeri.

\section{METODE PENELITIAN}

Penelitian ini menggunakan metode studi kasus. Nilai unik dalam penelitian ini adalah adanya pemahaman petugas kehumasan tentang peran humas pemerintah di Kementerian Dalam Negeri. Penelitian ini tergolong satu obyek (single case study), karena penulis akan melakukan penelitian terhadap satu kasus. Keunikan dalam tema penelitian ini adalah dimana Permendagri 13/2011 merupakan satusatu regulasi setingkat Peraturan Menteri di Indonesia yang mencoba untuk merevitalisasi peran humas di dalam lingkungan lembaga 
mereka. Esensi penguatan peran humas

Kemendagri secara internal kemudian menjadi menarik karena sesuai dengan nilai humas sebagai salah satu peran manajemen sebuah lembaga.

Penelitian ini menentukan key informan yang akan menjadi narasumber bagi pengumpulan data yang dipilih secara purposif. Teknik ini dipilih berdasarkan pertimbangan rasional peneliti bahwa informanlah yang memiliki otoritas dan kompetensi untuk memberikan informasi atau data sebagaimana diharapkan peneliti. Informan dipilih sebagai narasumber karena penulis menganggap bahwa informan tersebut memiliki informasi yang diperlukan dalam penelitian ini. Informan yang berasal dari pelaksana peran humas pemerintah di instansi Kemendagri dianggap tepat oleh peneliti untuk memberikan data yang relevan karena melaksanakan peran humas pemerintah secara langsung dan dapat memberikan data yang mendalam. Teknik pemeriksaan keabsahan data dilakukan melalui triangulasi sumber.

\section{HASIL DAN PEMBAHASAN}

Peran humas menurut praktisi humas Kemendagri dalam sebuah lembaga baik swasta maupun pemerintah adalah sangat penting. Keberadaan profesi ini dalam sebuah lembaga berperan untuk menciptakan goodwill publik terhadap lembaga, maupun sebaliknya mengkomunikasikangoodwill lembaga terhadap publiknya. Selain membangun goodwill, humas pemerintah juga menjalan peran menjaga hubungan baik pemerintah dengan stakeholder atau pemangku kepentingan seperti media baik lokal, nasional maupun internasional. Selain media hubungan yang baik juga harus dibangun adalah antara pemerintah dengan masyarakat atau warga negara, hubungan dengan organisasi lain yang memiliki kepentingan dengan Kemendagri. Hal ini muncul dari pendapat Andri Indrawan, dari Kemendagri berikut ini : "Peranan humas sangat penting sekali. Humas berperan untuk menjaga goodwill, menjaga hubungan baik pemerintah dengan stakeholder baik itu media maupun masyarakat dan organisasi, membangun pemahaman masyarakat tentang kebijakan pemerintah, membangun kepercayaan masyarakat terhadap pemerintah."

Mengacupadapendapattersebutpula, humas kemendagri juga mempunyai peran yang sangat penting dalam upaya membangun pemahaman masyarakat tentang kebijakan pemerintah yang dalam hal ini adalah kemendagri. Dan tak kalah pentingnya peran humas Kementerian dalam negeri adalah membangun kepercayaan (trust) masyarakat terhadap sebuah pemerintahan. Lahirnya goodwill, harmonisnya hubungan, terbangunnya pemahaman dan kepercayaan stakeholder terhadap pemerintah merupakan tujuan dari keberadaan profesi humas pemerintah, khususnya Humas Kemendagri. 
Pernyataan mengenai peran humas di sebuah lembaga yang dikemukakan oleh humas Kemendagri, sejalan dengan tugas humas pemerintah yang diungkapkan oleh Effendi dalam (Aras, 2014) yakni,

"Pertama, kebijaksanaan perencanaan dan hasil yang telah berhasil dicapai diinformasikan oleh humas lembaga secara teraatur; Kedua, mendidik dan menerangkan perundang-undangan, peraturan-peraturan dan hal yang bersakngkutan dengan aspek kehidupan masyarakat."

Melalui pernyataan yang dikemukakan oleh humas Kemendagri bahwa sebuah lembaga harus membangun goodwill antara publik dengan lembaga maupun sebaliknya menunjukan bahwa Humas Kemendagri telah sesuai dengan tugas Humas Pemerintah.

Untuk menjalankan perannya praktisi humas Kemendagri masih perlunya untuk melakukan revitalisasi peran serta peran humas pemerintah secara umum. Andri Indrawan, dari Kemendagri menegaskan bahwa dibutuhkan upaya revitalisasi kembali peran humas pemerintah. Karena menurut beliau dewasa ini masih ditemukan lembaga-lembaga pemerintah yang menganggap posisi atau bagian humas dalam sebuah lembaga tersebut sebagai tempat atau posisi buangan bagi sumber daya manusia (SDM) pemerintahan yang kurang produktif. Ada kalanya, bagian humas dalam sebuah lembaga dijadikan tempat 'menghukum' orangorang yang kalah dalam sebuah percaturan 'office politicking' sebuah lembaga, seperti yang dikemukakan Andri Indrawan, dari Kemendagri:

"Merevitalisasi kembali peran humas yang sudah ada. Namun humas masih dianggap sebagai tempat buangan, terlihat dari background pendidikan pimpinan dan pejabat kehumasannya yang bukan dari humas. Sebenarnya institusi kehumasan itu ada, namun kurang mendapatkan tempat."

Selain karena masih ditemukannya bagian humas yang dijadikan tempat buangan bagi SDM yang 'bermasalah', revitalisasi peran humas dilakukan melalui pembenahan latar belakang pendidikan para praktisi yang menduduki posisi humas sebuah lembaga pemerintah. Para pelaku humas sebuah lembaga pemerintah, baik pada level pimpinan maupun staf, seharusnya mempunyai latar pendidikan ilmu humas atau paling tidak komunikasi. Hal ini ditujukan agar dalam melaksanakan tugasnya, praktisi humas pemerintah terbekali dengan pemahaman dan pengalaman yang memadai dalam bidang kehumasan.

Faktor yang penting untuk diperhatikan dalam pelaksanaan peran humas pemerintah adalah sumber daya manusia sebagai pelaksana peran humas. Dalam penelitian yang dilakukan oleh (Lubis, 2012) dinyatakan jika SDM yang tidak dapat memenuhi peran humas, dapat menjadi faktor penghambat salah satu tujuan dilakukannya peran humas pemerintah. Dalam hal ini adalah pembentukan citra lembaga. 
Fenomena latar belakang pendidikan kehumasan menjadi sangat krusial dalam upaya merevitalisasi peran humas pemerintah, karena berkaitan dengan eksistensi humas dalam sebuah lembaga. Bagaimana mungkin pelaku kehumasan dapat menjalankan perannya yang ideal jika tidak atau minim dibekali pengetahuan dan pemahaman yang ideal. Pendidikan humas paling tidak akan menjadi modal yang cukup kuat bagi humas pemerintah untuk menjalankan peran dan perannya dalam sebuah lembaga. Akhirnya berjalannya peran humas pemerintah secara ideal akan menjadi modal humas pemerintah untuk mencapai eksistensinya dalam sebuah lembaga.

Berdasarkan pernyataan di atas mengenai perlunya dilakukan revitalisasi peran humas pemerintah, sebaiknya dilakukan oleh lembaga pemerintah yang menjalankan peran humas didalamnya. Hal ini menjadi penting karena pada strategi jangka panjang, pranata humas menjadi bagian dari proses pengambilan keputusan, memberi saran gagasan dan ide yang dapat berpengaruh pada kelangsungan institusi (Aras, 2014).

Keberadaan profesi humas pemerintah pada hakekatnya merupakan perwakilan sebuah lembaga pemerintah dalam menjalankan perannya sebagai pelayan masyarakat. Sementara pengertian pelayan masyarakat adalah dalam setiap kebijakan yang dikeluarkan oleh sebuah lembaga pemerintahan merupakan serangkaian upaya pemerintah untuk meningkatkan pelayanan kepada masyarakat. Agar sebuah produk kebijakan yang dikeluarkan oleh pemerintah benar-benar mampu menjawab kebutuhan masyarakat, maka dibutuhkan peran humas untuk untuk membangun komunikasi dua arah dengan publik.

Dalam melakukan perannya sebagai komunikator, humas pemerintah harus melakukan komunikasi interaktif dengan media massa atau pers. Salah satu melalui media massa, humas pemerintah dapat menyampaikan informasitentang kota secara lebih komprehensif (Wahyudin \& Erlandia, 2018).

Hal ini berguna untuk menjaring aspirasi masyarakat, menangkap kebutuhan-kebutuhan dan permasalahan-permasalahan masyarakat. Hasil penjaringan informasi ini disampaikan humas pemerintah pada pimpinan atau pihakpihak yang berwenang dalam membuat sebuah regulasi atau kebijakan, seperti yang disampaikan Andri Indrawan, dari Kemendagri: "Disinilah letak pemerintah sebagai pelayan masyarakat. Artinya kebijakan, program yang dikeluarkan pemerintah adalah dalam rangka meningkatkan pelayanan kepada masyarakat. Makanya selalu kita bangun komunikasi timbal balik, agar dapat menjaring aspirasi masyarakat kebijakan yang baru itu seperti apa dan kurangnya apa. Kadang harus ada revisi peraturan, karena kita lihat adanya dinamika sudah berubah, tidak sama seperti yang lalu. Dari hasil evaluasi bersama masyarakat, kita kelola lagi untuk memperbaiki kebijakankebijakan kita yang sebelumnya". 
Komunikasi dua arah merupakan aspek yang penting dalam peran Humas Pemerintah. Karena komunikasi dua arah yang dibangun humas pemerintah juga merupakan medium evaluasi bagi regulasi pemerintah. Humas pemerintah menangkap feedback dari masyarakat, bagaimana respon mereka terhadap kebijakan yang dikeluarkan pemerintah, serta apa masukan mereka untuk bahan evaluasi sebuah produk kebijakan pemerintah. Untuk mendapatkan feedback lebih efektif, humas pemerintah dapat mengoptimalkan kemajuan teknologi informasi pada perangkat komunikasi lembaga.

Berdasarkan hasil penelitian yang dilakukan oleh (Graham, 2014) dengan menggunakan sistem e-government, Pemerintah bisa lebih terbuka menerima feedback dan efisien serta dapat lebih aktif dalam menghimpun masukan dari publik sehingga feedback yang diberikan dapat menjadi bagian dari proses pemerintahan. Selain menginformasikannya melalui media sosial atau dengan menggunakan konsep e-government, pemerintah juga sebaikanya melakukan komunikasi dua arah secara langsung pada masyarakat melalui media komunikasi konvensional (Haryanti, 2018).

Penerjemahan peran humas di lapangan banyak seninya, artinya pelaksanaan peran humas di pusat bisa berbeda dengan di daerah. Salah satu faktornya adalah gaya, selera hingga dukungan pimpinan terhadap pelaku humas dalam sebuah lembaga pemerintah. Selain itu adanya otonomi daerah yang memberikan otoritas daerah untuk mengelola kegiatan pemerintahannya sesuai dengan aspirasi dan kebutuhan daerah masing-masing (Djusan, 2012). Kedua hal tersebut memberikan celah perbedaan persepsi peran Humas pada lembaga Pemerintah. Agar penerjemahan peran humas tidak beragam maka dibutuhkan regulasi seperti Permendagri 13/2011. Fenomena menarik dapat ditangkap dalam penuturan Pak Andri Indrawan berikut ini

"Humas ini banyak seni di lapangan, karena sifatnya tidak bisa baku. Karena di lapangan sifatnya beda-beda. Kita juga hanya memberikan pedoman dan acuan. Termasuk kondisi humas di daerah juga lain. Ada yang mendapat dukungan dari pimpinan, ada juga yang begitu saja. Apalagi dengan pilkada, kepala daerah bisa dari mana saja. Politisi, ulama, akademisi, macam-macam. Rata-rata mereka membawa tim sukses, dan merekalah yang menjadi humasnya mereka. Sehingga peran humas pemerintah sendiri jadi berkurang. Lebih banyak kegiatan temu wartawan, advertorial, dan sebagainya dilakukan oleh tim sukses ini".

Dalam era pemilihan pemimpin daerah secara langsung dewasa ini membuka kesempatan pada siapa saja dengan kompetensi dan potensinya untuk mencalonkan diri menjadi pimpinan daerah selevel gubernur, walikota atau bupati. Kompetisi para calon pemimpin daerah dalam sebuah pemilu kepala daerah (Pilkada) memunculkan pula tren lahirnya kelompok 
pendukung yang biasa disebut tim sukses. Tim ini dibentuk untuk melakukan serangkaian upaya pemenangan calon pemimpin tertentu. Jika seorang calon pemimpin daerah berhasil memenangkan pilkada, menurut pengamatan dan pengalaman Pak Andri Indrawan, dia akan 'membawa' beberapa tokoh dalam tim suksesnya untuk 'masuk' ke dalam inner circle kekuasaan.

Kepala daerah pemenang pemilu akhirnya seolah menyediakan tempat atau lebih tepatnya pekerjaan bagi anggota tim sukses ini di dalam pemerintahan. Karena jalur untuk mengangkat mereka sebagai pegawai negeri sipil panjang dan berliku, maka mereka 'mempekerjakan' tim sukses pada porsi staf atau tenaga ahli. Ironisnya, kebanyakan staf ahli ini dalam kesehariannya menjalankan peran 'membangun citra' pribadi kepala daerah. Bahkan cepat atau lambat staf ahli ini semakin mengambil porsi pelaku humas pemerintahan yang sebenarnya di daerah tersebut. Akhirnya peran humas pemerintah, formal (resmi), tersaingi oleh 'humas dadakan' ini. Maka Permendagri 13/2011 adalah regulasi yang diharapkan mampu memperkuat, melindungi serta merevitalisasi humas pemerintah, dalam hal ini di daerah. Sebagaimana diketahui bahwa Permendagri 13/2011 merupakan pedoman bagi penyelenggaraan aktivitas kehumasan di lingkungan Kemendagri (Pusat) dan pemerintah daerah (provinsi, kota dan kabupaten).

Permendagri 13/2011 juga dipahami oleh pelaku humas kemendagri sebagai landasan hukum formal bagi pelaku kehumasan Kemendagri untuk berubah. Hal tercermin dari pendapat Simon Saimima, dari Kemendagri, berikut :

"Humas itu mempunyai peranan yang sangat penting dalam membentuk satu opini bagi sebuah lembaga. Dalam hal ini, kami kementrian dalam negeri, humas sebagai lembaga yang membentuk opini dan citra lembaga, baik buruknya lembaga itu ada di humas. Itu yang pertama. Kedua, pejabat kehumasan itu sendiri untuk pemerintah yang dulu berbeda dan kekinian. Lambat dalam menyebarkan informasi. Semua itu merupakan rahasia. Tetapi dengan adanya keterbukaan yang kita bangun dengan Permendagri Nomor 13, kita mencoba mendobrak sekat-sekat itu, kita menampilkan wajah, ini loh humas pemerintah, seperti ini”".

Sebagai sebuah bagian dalam lembaga pemerintahan, humas mempunyai peranan untuk membentuk opini publik tentang lembaganya. Dimana masih menurut Pak Simon, baik buruknya sebuah lembaga tergantung dari peran humasnya membangun opini dan citra lembaga. Dalam menjalankan perannya ini, terdapat perbedaan antara humas pemerintah di masa lalu dan humas pemerintah masa kini.

Dahulu humas pemerintah menghadapi sekat-sekat informasi sehingga menghambat tugas humas untuk membangun opini publik dengan lugas dan ideal. Permendagri 13/2011 hadir untuk merobohkan sekat- 
sekat penghalang informasi tadi. Sehingga Humas Kemendagri memiliki akses informasi, mendapatkan suplai informasi, mengolah dan menyebarluaskan informasi tersebut pada publik secara proporsional dan tepat sasaran. Semua dalam koridor upaya membentuk opini publik kepada lembaga.

Upaya pembentukan opini publik terhadap pemerintah, tak lepas dari pentingnya kemampuan pelaku kehumasan kemendagri untuk mampu menjadi news maker bagi lembaganya. Berikut penuturan Simon Saimima, dari Kemendagri:

"Humas pemerintah bukan hanya fotografi, membuat kliping, menanggapi berita, membuat hak jawab, atau hak klarifikasi dan seterusnya, memfasilitasi wartawan, tapi juga sebagai news maker, pembuat berita".

Kemampuan menjadi news maker melengkapai kemampuan kehumasan lain seperti fotografi, media monitoring, kliping, menanggapi pemberitaan media, membuat hak jawab pada media hingga mengklarifikasi pemberitaan tertentu di media. News maker merupakan kemampuan pelaku kehumasan untuk membuat lembaganya menjadi berita di media massa. Produk-produk regulasi, kebijakan, program hingga kegiatan-kegiatan lembaga harus mampu muncul menjadi berita di media massa.

Kemampuan membuat berita pelaku kehumasan kemendagri harus ditunjang oleh ketersediaan bahan informasi yang bisa diolah dan dikemas menjadi berita yang menarik dan memiliki nilai berita bagi media. Artinya humas kemendagri butuh jaminan akses informasi pada sumber-sumber informasi di setiap bagian kementrian. Permendagri 13/2011 sekali lagi adalah regulasi pembuka akses informasi bagi pelaku kehumasan kemendagri. Sehingga informasi tentang kebijakan, program hingga kegiatan-kegiatan lembaga akan dapat diakses, kelola dan dikemas menjadi informasi yang penuh nilai berita.

Pernyataan mengenai peran humas pemerintah yang sebaiknya memiliki kemampuan sebagai news maker untuk membentuk opini tentang lembaganya sudah sesuai. Berdasarkan hasil penelitian yang dilakukan oleh (Hopkins, 2015) jika praktisi Humas dapat membaca karakter media dimana lembaga tersebut berada, maka Humas lembaga dapat membentuk opini publik di wilayah tersebut. Kemampuan ini diperlukan oleh humas pemerintah untuk menjalankan peran humas sebagai news maker termasuk humas kemendagri.

Staf kemendagri lainnya, Andi Kriarmoni mengomentari mengenai peran humas sebagai bagian yang penting dalam sebuah lembaga pemerintahan :

"Menurut kami humas ini sangat penting, karena merupakan ujung tombak, bemper, 
wajah, front office yang pertama kali akan bersentuhan dengan pihak luar badan organisasi. Untuk itu kesan pertama, pandangan pertama, ucapan pertama, keterangan pertama menjadi awal masuk sebuah persepsi dari pihak di luar organisasi akan memandang bagaimana organisasi ini berinteraksi”.

Bagi Pak Andi humas memegang peranan penting sebagai wajah organisasi yang langsung akan berhadapan dengan pihak di luar lembaga. Pelaku kehumasan Kemendagri sebagai wajah organisasi berperan menciptakan kesan pertama yang positif yang akan melahirkan persepsi pihak luar kepada lembaganya secara positif pula. Pada gilirannya, persepsi pihak luar pada lembaga akan menentukan bagaimana cara pandang mereka pada lembaga. Jika persepsi terbangun positif, maka cara pandang mereka terhadap lembaga pun akan positif. Persepsi dan cara pandang yang positif ini pula yang akan mewarnai interaksi lembaga dengan pihak tersebut.

Interaksi harmonis lembaga dan pihak luar adalah esensi dari peran humas pemerintah secara keseluruhan. Interaksi harmonis ini tidak mungkin dicapai tanpa kemampuan pelaku kehumasan menciptakan persepsi positif publik terhadap lembaganya. Untuk mampu menciptakan persepsi positif publik pada lembaga, pelaku kehumasan pemerintah harus mampu menciptakan terlebih dahulu kesan pertama yang positif pula. Sehingga perlu sebuah regulasi untuk mendorong humas pemerintah guna memainkan peran sebagai wajah organisasi.

Terkait peran humas kemendagri sebagai wajah organisasi, Indra Simaremare dari Kemendagri, mempunyai pendapat :

"Peran humas itu sangat strategis untuk institusi pemerintahan, karena dia menjadi corong yang akan menyampaikan semua informasi yang terkait dengan kebijakan yang akan diambil sebuah institusi, dan bertugas untuk membuat pencitraan yang lebih baik. Itu peran penting dari humas."

Peran humas kemendagri sebagai corong yang dimaksud oleh Pak Indra adalah peran menghimpun, mengolah, mengemas dan menyebarluaskan informasi berupa kebijakan lembaga kepada publik sehingga tercipta citra positif publik terhadap kebijakan pada khususnya dan lembaga pembuat kebijakan pada umumnya. Peran ini dinilai Pak Indra sebagai peran yang sangat strategis.

Peran strategis humas ini kurang dipahami secara proporsional oleh pelaku kehumasan di tingkat daerah. Pelaku kehumasan daerah masih melihat jabatan atau posisi humas dalam lembaganya sebagai posisi yang tidak terlalu penting, posisi tempat orang-orang (SDM) yang terbuang dan tidak memiliki pengaruh dalam keberlangsungan sebuah lembaga pemerintahan. Alhasil, jabatan atau posisi humas pemerintah dianggap tidak strategis bagi lembaga terlebih pada personal mereka sendiri. Seperti yang 
dinyatakan oleh Indra Simaremare:

"Adanya Permendagri No 13 tahun 2011 ini karena perlunya pemerintah daerah ini memahami tugas penting humas, karena selama ini dianggap tidak ada dan bukan merupakan jabatan yang tidak strategis, jadi makanya diterbitkanlah Permendagri No 13 tahun 2011 ini tentang tugas-tugas kehumasan, apa peran dan peran humas semuanya ada di situ."

Permendagri 13/2011 diharapkan mampu memberikan petunjuk bagi pemerintah daerah baik pada level pimpinan daerah maupun pelaku kehumasan di daerah untuk lebih memahami posisi strategis jabatan humas di lembaga mereka. Permendagri 13/2011 diharapkan mampu membangun kesadaran institusi sekaligus personal tentang pentingnya menyelenggarakan kegiatan-kegiatan kehumasan di daerah demi terciptanya citra lembaga sekaligus juga citra daerah mereka.

Lebih lanjut, Indra Simaremare menyoroti pula keterkaitan posisi strategis humas dalam sebuah lembaga pemerintahan dengan persoalan eselonisasi yang memang khas di institusi pemerintah. Eselonisasi berkaitan dengan kepangkatan SDM dalam sebuah institusi pemerintah. Sederhananya, pangkat individu yang lebih rendah akan menemukan kesulitan untuk meminta informasi dan berinisiatif koordinasi dengan individu lain yang pangkatnya lebih tinggi dalam lembaga tersebut. Pak indra memiliki harapan agar pemimpin bagian Humas Kemendagri, dalam hal ini Kapuspen Kemendagri dijabat oleh seseorang yang memiliki golongan/pangkat lebih tinggi lagi.

"Sebenarnya dengan tupoksi yang ada di eselon dua seperti peran koordinasi dan minta data dan sebagainya, itu kurang tepat, harusnya eselon satu. Ibarat di TNI itu, ada Kadiv Humas Mabes Polri.”

Seharusnya Kapuspen Kemendagri adalah seseorang dengan pangkat eselon satu (1) seperti yang sudah diterapkan di institusi seperti Tentara Nasional Indonesia (TNI) atau Kepolisian Republik Indonesia (Polri). Walaupun dengan adanya Permendagri 13/2011 sebenarnya permasalahan keterbatasan 'ruang gerak' humas kemendagri terkait dengan eselon Kapuspen yang lebih rendah dari pejabatpejabat sumber informasi di Kemendagri sudah menemukan solusinya.

Permendagri 13/2011 mengatur tentang alur informasi dalam tubuh Kemendagri. Pelaku kehumasan dibukakan akses untuk meminta informasi dan membuka inisiatif berkoordinasi dengan pejabat-pejabat dengan tingkat eselon lebih tinggi semisal Menteri, para Direktorat Jenderal dan Sekretariat Jenderal. Bahkan Permendagri 13/2011 juga memberi petunjuk pada pejabat eselon satu untuk mem-forward ke bagian humas dan memberi informasi yang dibutuhkan pelaku kehumasan di lingkungan Kemendagri. Hal itu tercermin dari keterangan staf Kemendagri, Reydonnizar Moenek, berikut 
ini :

"Kenapa kita melekat pada komponen Sekertariat Jenderal, karena saya langsung dengan menteri, saya bisa langsung dengan sekjen, saya bisa langsung minta informasi dan kita bisa langsung koordinasikan kepada seluruh eselon I kita tanpa terhalang dan terhambat dengan kendala eselonisasi saya. Anytime anywhere saya bisa angkat telepon dengan siapa pun. Saya bisa telpon gubernur, saya bisa telpon bupati, eselon I, menteri saya bisa telpon semua. Ngga terkendala oleh itu."

Selain membuka akses informasi dua arah baik vertikal maupun horisontal, Permendagri 13/2011 juga memberikan peran yang sangat strategis bagi posisi Kapuspen Kemendagri. Kapuspen memiliki wewenang yang luas untuk memberi informasi pada publik secara lengkap, lugas dan proporsional. Bahkan dalam banyak kesempatan Kapuspen memberikan informasi, seperti memberi keterangan pada media massa tanpa harus berkoordinasi instansi terkait terlebih dahulu.

Walaupun setelah memberi keterangan tersebut Kapuspen melanjutkannya dengan koordinasi dengan instansi terkait yang dimaksud, seperti yang diungkapkan oleh Reydonnizar Moenek:

"Dalam pengalaman saya pribadi dengan Pak Menteri, Menteri dalam Negeri selalu memberi keleluasaan dan kebebasan kepada saya selaku Kapuspen atau Juru Bicara. Saya, whatever saya berbicara apapun, saya dengan daya analitis dan daya evaluatif, tapi seberapa penting dan seargumentatif apakah penjelasan itu. Itulah yang paling penting."
Peran dan posisi humas kemendagri yang strategis dirasakan Kapuspen Kemendagri sebagai jabatan yang menyandang amanah yang sangat berat. Menjalankan peran sebagai komunikator lembaga, mewakili lembaga, membutuhkan penguasaan pesan lembaga dari tataran filosofis hingga level teknis. Pengetahuan tentang aspek tersebut harus pula dilengkapi dengan kemampuan analisa dan evaluasi yang bagus. Sehingga pesan berupa informasi yang keluar dari pelaku kehumasan Kemendagri memiliki nilai informasi yang tinggi, lengkap serta akurat. Tidak hanya sampai disitu, pelaku kehumasan Kemendagri juga harus melakukan konfirmasi atau mengklarifikasi informasi yang berkembang dalam hubungan dengan publik secara menyeluruh. Hal ini diakui oleh Pak Donny, panggilan akrab Reydonnizar Moenek. "Harus saya akui, ini tempat yang paling berat, karena mengandung konsekuensi. Namun saya selalu berprinsip I'll do my best. Care, share, fair. Saya juga membangun dengan well managed, well maintained, well performed, dan well informed."

Akan tetapi dengan payung regulasi Permendagri 13/2011, aktivitas kehumasan yang strategis namun berat karena mengandung banyak konsekuensi itu, seolah mendapat dukungan, kepercayaan dan ruang gerak yang semakin dinamis bagi pelaku kehumasan kemendagri untuk menjalan peranan dan peran Humas yang ideal dan proporsional. Hal ini 
sangat memungkinkan sepanjang masingmasing pelaku kehumasan piawai dalam mengatur ritme kerja, mahir dalam memelihara kinerja, pandai dalam menampilkan diri dan idenya serta cakap untuk menginformasikan pesan lembaga dalam koridor regulasi yang kuat dan jelas. Adapun model pemahaman mengenai peran Humas pemerintahan menurut petugas kehumasan di Kemendagri dapat digambarkan pada gambar 1 .

Humas juga berperan untuk mewakili aspirasi masyarakat melalui proses komunikasi yang efektif sehingga Humas bisa menjadi bagian dari kemajuan sebuah lembaga atau daerah (Ristanto, 2015) Untuk mencapai peran humas pemerintah tersebut, diperlukan komunikasi dengan publik melalui media baik media konvensional maupun elektronik.

Oleh karena itu Humas Pemerintah harus menggunakan media dengan optimal karena humas pemerintah memiliki beberapa pendekatan salah satunya adalah “...melayani

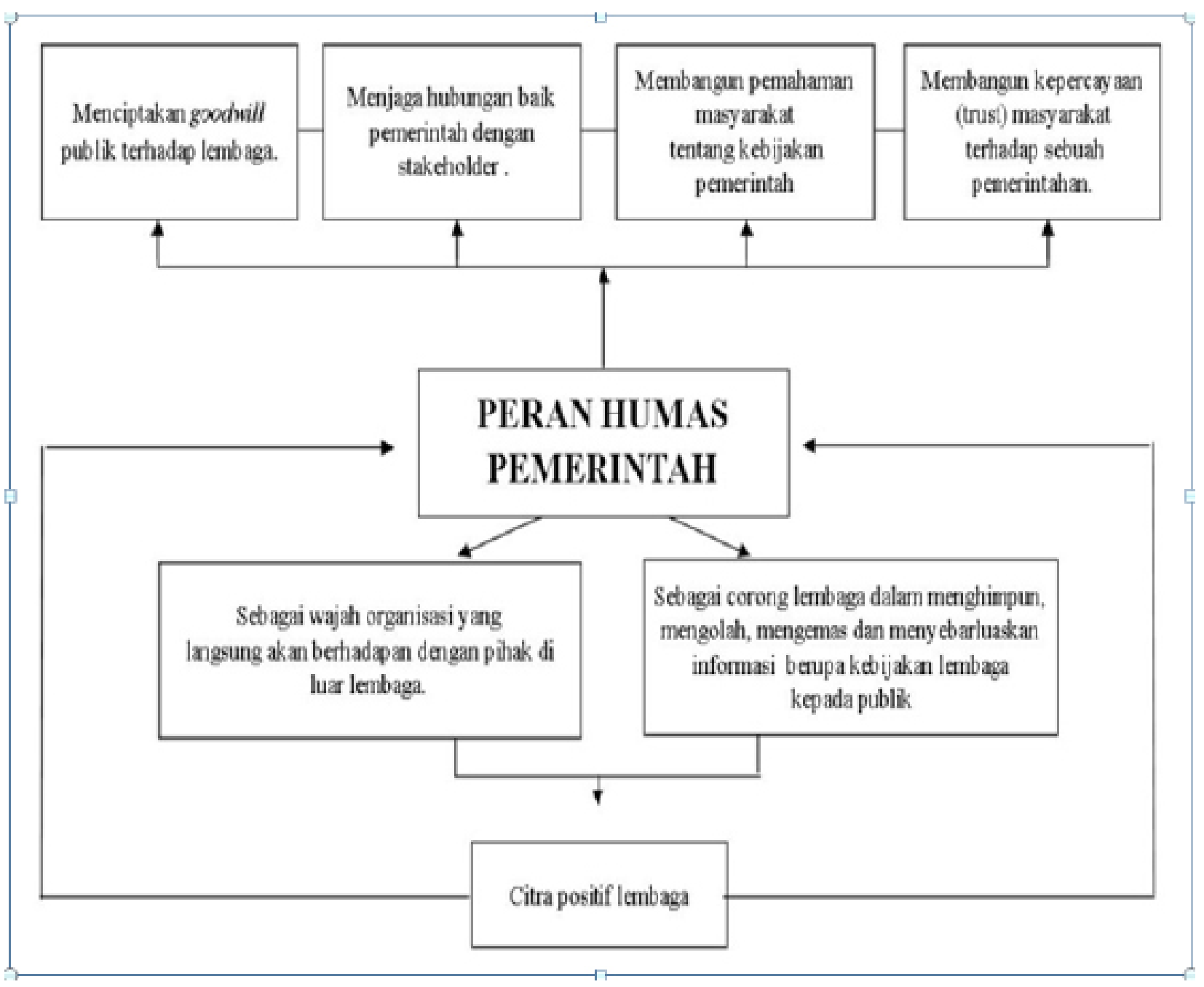

Sumber: Hasil Penelitian, 2013

Gambar 1 Model Pemahaman Petugas Kehumasan Kemendagri Tentang Peran Humas Pemerintahan 
informasi pada publik" (Idris, 2014). Sehingga dengan memahami karakteristik media dapat menjalankan pendekatan humas pemerintah tersebut.

Sebaiknya humas pemerintah bisa berinteraksi lebih inovatif, berpikir aktif, dan menyampaikan informasi berdasarkan data. Realitasnya masih ada hubungan masyarakat pemerintah yang memahami peran hubungan masyarakat pemerintah hanya sebagai peran pencitraan semata, yaitu bagaimana caranya membuat kesan positif kepada rakyat dengan menyampaikan informasi-informasi yang cenderung satu sisi semata. Tantangan Public relations Pemerintah di era Demokrasi saat ini memanglah tidak mudah, oleh karena itu diperlukan kreatifitas serta inovasi-inovasi untuk mendapatkan dukungan dari rakyat dan meningkatkan partisipasi rakyat dalam menjalankan kebijakan pemerintah. Salah satunya bisa diterapkan melalui e-government yang dapat mendukung peran Humas. Berdasarkan hasil penelitian oleh (Trisnani, 2018) diketahui bahwa penggunaan teknologi padaaktivitase-government dapatmeningkatkan pelayanan publik seperti kebutuhan informasi publik. Aspek tersebut merupakan salah satu peran Humas Pemerintahan yang tentunya bisa dioptimalkan melalui inovasi.

Komunikasi yang kita lakukan tentu mempunyai maksud dan tujuan serta beragam intinya. Salah satu tujuan komunikasi adalah mencapai pengertian bersama. Hal itu sudah tentu sangat dimaklumi dan diperhatikan oleh sebuah lembaga/institusi. Dalam menciptakan pengertian bersama ini salah satunya adalah untuk memelihara hubungan yang baik antara lembaga/institusi dengan publik atau masyarakatnya. Dalam hal inilah aktivitas hubungan masyarakat sangat dibutuhkan.

Pernyataan W. Emerson Reek, Public relations Director, Colgate University, yang dikutip tersebut, memperlihatkan bahwa public relations adalah kelanjutan dari proses penetapan kebijakan, pertentuan pelayananpelayanan dari sikap yang disesuaikan dengan kepentingan orang-orang atau golongan agar orang-orang atau lembaga tersebut memperoleh kepercayaan dan goodwill dari mereka, kemudian selanjutnya pelaksaan, pelayanan dan sikap adalah untuk menjamin adanya pengertian dan penghargaan dengan sebaik-baiknya.

Hubungan masyarakat bukanlah ilmu tradisional yang digunakan untuk menghadapi tujuan-tujuan sesaat. Hubungan masyarakat perlu direncanakan (planned), dalam suatu pendekatan manajemen kepada target-target publik tertentu. Public relations melakukan komunikasidengancaramembujuk(persuasive). Oleh karena itu sering disebut bahwa profesi PR adalah profesi pembujuk (persuader). Kata kunci significant public mengacu pada khalayak 
sasaran pekerjaan PR. Khalayak sasaran ini disebut stakeholder. Stakeholder adalah setiap kelompok yang berada di dalam ataupun di luar perusahaan yang mempunyai peran dalam menentukan keberhasilan perusahaan. Stakeholder bisa pula berarti kelompok penekan (pressure group) yang mesti dipertimbanakan perusahaan (Kasali, 2005).

Definisi hubungan masyarakat yang lainnya disampaikan oleh (Cutlip, Center, \& Broom, 2000) hubungan masyarakat merupakan peran manajemen dari sikap budi yang direncanakan dan dijalankan secara berkesinambungan oleh organisasi-organisasi, lembaga-lembaga umum dan pribadi dipergunakan untuk memperoleh dan membina saling pengertian, simpati dan dukungan dari mereka yang ada hubungan dan diduga akan ada kaitannya, dengan cara menilai opini publik mereka, dengan tujuan sedapat mungkin menghubungkan kebijaksanaan dan ketatalaksanaan, guna mencapai kerja sama yang lebih produktif, dan untuk memenuhi kepentingan bersama yang lebih efisien, dengan kegiatan penerangan yang terencana dan tersebar luas.

\section{SIMPULAN}

Humas pemerintah berperan untuk menciptakan good will publik terhadap lembaga, maupun sebaliknya mengkomunikasikan goodwill lembaga terhadap publiknya. Selain membangun goodwill, humas pemerintah juga menjalan peran menjaga hubungan baik pemerintah dengan stakeholder atau pemangku kepentingan seperti media baik lokal, nasional maupun internasional. Selain dengan pihak media, hubungan baik yang juga harus dibangun adalah antara pemerintah dengan masyarakat atau warga negara, hubungan dengan organisasi lain yang memiliki kepentingan dengan Kemendagri.

Selain itu, peran yang diemban humas pemerintahan adalah membangun pemahaman masyarakat tentang kebijakan pemerintah yang dalam hal ini adalah Kemendagri. Dan tak kalah pentingnya peran humas kementerian dalam negeri adalah membangun kepercayaan (trust) masyarakat terhadap sebuah pemerintahan. Lahirnya goodwill, harmonisnya hubungan, terbangunnya pemahaman dan kepercayaan stakeholder terhadap pemerintah merupakan tujuan dari keberadaan profesi humas pemerintah, khususnya humas kemendagri.

Peran humas juga dianggap sebagai wajah organisasi yang langsung akan berhadapan dengan pihak di luar lembaga. Oleh karena itu, pelaku kehumasan kemendagri sebagai wajah organisasi berperan menciptakan kesan pertama yang positif yang akan melahirkan persepsi pihak luar kepada lembaganya secara positif pula. Peran lain yang harus dapat dilakukan adalah peran strategis sebagai corong lembaga 
dalam menghimpun, mengolah, mengemas dan menyebarluaskan informasi berupa kebijakan lembaga kepada publik sehingga tercipta citra positif publik terhadap kebijakan pada khususnya dan lembaga pembuat kebijakan pada umumnya.

\section{DAFTAR PUSTAKA}

Aras, M. (2014). Kegiatan government public relation dalam membangun komunikasi dengan dunia pers: studi kasus humas pemerintah kota administrasi Jakarta Timur. Jurnal Humaniora, 5(2), 10561065. https://doi.org/1056-1065.

Astuty, S., Setyastuti, Y., Maulina, N., \& Hanief, L. (2017). Analisis fungsi dan peran humas dalam upaya implementasi good governance. Jurnal of Communication Studies, 2(1), 100-118.

Cutlip, S. M., Center, A. H., \& Broom, G. M. (2000). Effective Public Relations. (E. Editions, Ed.). New Jersey: Prentice Hall Inc.

Djusan, A. (2012). Praktik government public relations paska otonomi daerah. Jurnal Studi Komunikasi Dan Media, 16(1), 6170.

Graham, M. W. (2014). Government communication in the digital age : Social media's effect on local government public relations. Public Relaitions Inquiry, 3(3), 361-376. https://doi. org/10.1177/2046147X14545371

Haryanti, S. (2018). Government public relations and social media: bridging the digital divide on people with social welfare problems. JKAP (Jurnal Kebijakan Dan Administrasi Publik), 22(2), 128-145. https://doi.org/ISSN 0852-9213.

Hopkins, A. E. (2015). Government public relations : public diplomacy or propaganda? Student Pulse, 7(03), 1-7. Retrieved from http:/www.inquiriesjournal.com/ articles/1012/government-public-relationspublic-diplomacy-or-propaganda.

Idris, I. K. (2014). Peran humas pemerintah di era keterbukaan iniformasi. Jurnal Universitas PAramadina, 11(6), 1147-1163.

Kasali, R. (2005). Manajemen public relations. Jakarta: Pustaka Utama Grafiti.

Kominfo. (2016). Humas pemerintah harus jadi andalan. Retrieved from https://www. kominfo.go.id/content/detail/8258/humaspemerintah-harus-jadi-andalan/0/berita satker.

Lubis, E. E. (2012). Peran humas dalam membangun citra pemerintah. Jurnal Ilmu Administrasi Negara, 12(1), 51-60.

RI, K. P. A. N. dan R. B. Pedoman umum tata kelola kehumasan di lingkungan instansi pemerintah (2011). Indonesia: jdih. ristekdikti.go.id > files > perundangan.

Ristanto, T.(2015). Peran humas pemerintah kota Balikpapan dalam mengimplementasikan konsep smart city di kota Balikpapan. Jurnal Universitas Airlangga, 4(1), 387-399. Retrieved from http://journal.unair.ac.id/ COMN@peran-humas-pemerintah-kotabalikpapan-dalam-mengimplementasikankonsep-smart-city-di-kota-balikpapanarticle-9324-media-137-category-8.html

Semangatnews. (2019). Mendagri: peran humas pemerintah itu menyeluruh sektor pembangunan. Retrieved October 23, 2019, from https://www.semangatnews. com/mendagri-peran-humas-pemerintahitu-menyeluruh-sektor-pembangunan/ 
Tench, R., \& Yeomans, L. (2006). Public relations (first edit). Spain: Pearson Education Limited.

Trisnani. (2018). Implementasi e-government public relations sebagai peningkatan pelayanan informasi publik di lingkungan pemerintah daerah di jawa timur dan nusa tenggara barat. Jurnal Komunikasi, Media Dan Informatika, 7(3).

Wahyudin, U., \& Erlandia, D. R. (2018). Peran humas pemerintah dalam pemasaran city branding melalui media massa. Jurnal Common, 2(2), 162-167 https://doi. org/10.34010/common.v2i2.1192. 